УДК 904 (470.6)

https://doi.org/10.24852/2587-6112.2020.6.301.315

\title{
ИЗ ИСТОРИИ ИЗУЧЕНИЯ СРЕДНЕВЕКОВОГО ВООРУЖЕНИЯ XIII-XIV ВВ. (ЮБИЛЕЙНАЯ И ПОЛЕМИЧЕСКИЕ ЗАМЕТКИ)
}

\author{
(С2020 г. Е.И. Нарожный
}

Предлагаемая статья состоит из трех небольших очерков. Первый очерк посвящен 60-летнему юбилею доктора исторических наук И.Л. Измайлова. Второй очерк содержит критический обзор версии польского исследователя В. Свентославского о реальности использования татаро-монголами в битве под Легницей (1241г.) «боевых отравляющих газов». Построенная на сведениях польского историка XV в. Яна Длугоша версия не имеет никаких серьезных оснований. Последний, третий очерк содержит обзор не всегда позитивного опыта характеристики украинским исследователем - доктором исторических наук Я.В. Пилипчуком (г. Киев) комплекса вооружения предков средневековых ингушей. Простой перечень известных категорий вооружения предков ингушей не дает ясного понимания процесса и динамики развития их военного дела, упрощая осознание всей сложности его формирования. Я.В. Пилипчук, уходя от демонстрации историографического наследия своих предшественников, допускает и неоправданные неточности. Среди них есть утверждения об использовании, например, эмиром Тимуром в Грузии «ружей и пушек». Все это превращает рассматриваемые им публикации в работы сомнительного научного качества.

Ключевые слова: юбилей И.Л. Измайлова, В. Свентославский о битве при Легнице, «боевые газы» монголов, Я.В. Пилипчук и комплекс вооружения средневековых ингушей, были ли «ружья и пушки» в войске Тимура.

\section{THE HISTORY OF THE STUDY OF MEDIEVAL WEAPONS OF THE 13TH-14TH CC. (ANNIVERSARY AND POLEMICAL ESSAYS)}

\section{E. I. Narozhny}

The paper features three short essays. The first essay is dedicated to the 60th Anniversary of Doctor of Historical Sciences I. L. Izmailov. The second essay contains a critical review of the version proposed by Polish researcher V. Sventoslavsky concerning the actual use of "combat poison gases" by the Tatar-Mongols in the Battle of Legnica (1241). Based on the information provided by Polish historian of the 15th century Jan Dlugosz, the version has no substantial grounds. The third essay contains an overview of the not always positive experience of characterization by Ukrainian researcher, Doctor of Historical Sciences Ya.V Pilipchuk (Kiev) of a complex of weapons of the ancestors of the medieval Ingush. A simple list of the known categories of weapons of the Ingush ancestors does not ensure a clear understanding of the process and dynamics of their military development, simplifying the understanding of the complexity of its formation. Ya. V. Pilipchuk, avoiding the demonstration of the historiographical heritage of his predecessors, is also subject to unjustified inaccuracies. For instance, they include claims about the use of "guns and cannons" by Emir Timur in Georgia. All this makes the publications considered by the researcher to be the works of questionable scientific quality.

Keywords: I. L. Izmailov's anniversary, V. Sventoslavsky about the battle of Legnica," battle gases "of the Mongols, Ya.V. Pilipchuk and the complex of weapons of the medieval Ingush, whether there were" guns and cannons " in the army of Timur.

Последние два года оказались чрезмерно насыщенными различными юбилейными датами коллег, друзей (Нарожный, 2019, с. 371-393), когда в нашем лексиконе довольно часто звучали слова: «юбилей», «юбиляр». Тогда же стали появляться юбилейные статьи и заметки и т. п. За каждым из таких «жизненных рубежей» - уже значительная часть прожитой жизни и при всей магии цифр, маркирующих тот или иной юбилей, - это лишь очередная «ступенька», жизненный этап, момент жизни, когда, чуть приостановившись, необходимо просто оглянуться назад и взвешенно оценить все то, что удалось сделать до нынешнего дня и что, самое главное, необходимо успеть сделать.

60-летие доктора исторических наук, заслуженного деятеля науки Республики Татарстан Искандера Леруновича Измайлова - не просто повод написать несколько теплых слов в его адрес. И.Л. Измайлов - известный и давно признанный ученый, специалист, прежде 
всего зарекомендовавший себя как хороший оружиевед и блестящий знаток военного дела, а также как глубокий исследователь археологии и истории Волжской Булгарии, Золотой Орды, истории и этнографии татар и Татарстана. Автор большого количества историко-археологических публикаций различного статуса, участник всевозможных научных форумов, сборов и конференций, серьезный рецензент и научный консультант, научный партнер. Несмотря на то, что большая часть нашего знакомства и взаимодействия проходит дистанционно, Искандер Лерунович всегда на связи, если нужно что-то уточнить, выяснить или же просто поделиться мнением или новостями. Несколько лет назад мы в совместном и едином порыве с И.А. Дружининой и В.Н. Чхаидзе (ИА РАН) загорелись идеей достойно почтить память московского археолога и историка М.В. Горелика, при своей жизни сыгравшего определенную роль в судьбе каждого из нас, и собрать посвященный ему сборник научных статей. Эту работу мы начали сразу же после смерти М.В. Горелика. Чуть позже появилась потребность привлечения к этой же работе и других исследователей, в т. ч. из Татарстана, и среди них, прежде всего, И.Л. Измайлова. Но обговорить эту идею с ним и А.М. Губайдуллиным удалось лишь в 2016 г., в Ялте, на международной конференции, посвященной памяти Г.А. Фёдорова-Давыдова. На все разговоры про сборник и его организацию ушло всего минут 15, и вскоре сборник статей не только был завершен, но и издан (Археология, 2017). И дело здесь не только в сроках или темпах этого издания - это такая черта характера Искандера Леруновича, как обязательность выполнения данного обещания, слова и дела. И она проявляется практически всегда, даже в рамках нашего преимущественно заочного общения.

Поздравляя юбиляра и присоединяясь к таким же поздравлениям друзей и коллег И.Л. Измайлова, я твердо убежден в том, что юбилей этот для него станет очередной замечательной датой в дальнейшей и плодотворной научно-творческой деятельности. Остается лишь искренне пожелать нашему юбиляру крепкого здоровья, научного задора и дальнейших исследовательских успехов! С юбилеем, Искандер Лерунович!

Теперь же остановимся на двух примерах изучения военной истории как татаро-монголов, так и северокавказских воинов в трактов- ке польского (В. Свентославский) и украинского (Я.В. Пилипчук) исследователей.

2. Об использовании татаро-монголами якобы «боевых газов» в 1241 г. под Легницей

В 1998 г. в Санкт-Петербурге в сборнике тезисов докладов международной научной конференции «Военная археология. Оружие и военное дело в исторической и социальной перспективе» были опубликованы тезисы доклада польского автора В. Свентославского (г. Лодзь) (Свентославский, 1998, с. 295-297), вскоре замеченного специалистами (Кадырбаев, с. 76-98). В 2012 г. тот же доклад, но уже расширенный до объема статьи, был опубликован в первом томе возрожденного сборника «Записки Восточного отделения Русского Археологического общества» (ЗВОРАО) (Свентославский, 2012, с. 393-379). Упомянутые доклад и статья были посвящены обоснованию достаточно неожиданного и экзотического «факта» - использованию монголо-татарами «боевых отравляющих газов» против средневековых поляков в 1251 г. в битве под Легницей (Свентославский, 1998, с. 295-297; 2012, с. 393-379).

Основным источником для польского исследователя в его аргументации этой точки зрения, как он подчеркивает сам, стало «детальное и очень образное описание», принадлежащее средневековому польскому автору «Яну Длугошу в его монументальном труде, представляющем историю польского королевства». Исходя из сообщений этого источника, современный польский автор свидетельствует: весной 1241 г., «опустошив территории польских княжеств, Моравы и Венгерского королевства», монголо-татары «в двух главных битвах этой кампании» якобы «применили нехарактерные для средневекового европейского воинства методы, которые оказались столь неожиданными и эффективными, что перед ними не смогло устоять европейское рыцарство». Первый такой пример был продемонстрирован уже «11 апреля 1241 г.» в «сражении под Мохи против венгров», когда «татаро-монголы применили камнеметные машины, ставя своей целью сокрушить переднюю линию неприятеля. Это был редкий пример использования ими таких боевых машин в полевых действиях» (Свентославский, 2012, с. 373).

Специалисты считают, что «у монгольских завоевателей, обрушившихся на Северный Китай в первой половине XIII в., процесс 
заимствования порохового оружия шел тем же путем, что и у их предшественников, чжурчжэней. Сообщения о первых осадах чжурчжэньских крепостей татаро-монголами свидетельствуют о применении ими камнеметного оружия опять-таки руками пленных и перешедших на их сторону китайских и чжурчжэньских артиллеристов. Когда в 1232 г. монгольская армия окружила столицу чжурчжэней Кайфэн, именно эти воины обрушили на стены города зажигательные снаряды (хо пао) и уничтожили защитные сооружения» (Школяр, 1980, с. 178). По данным китайского военного трактата «Шоу чэн лу» Чэнь Гуя, наиболее дальнобойные орудия (юань пао) могли поражать противника на расстоянии свыше 350 бу (более 535 м) (Майоров, 2016, с. 94-95). В многочисленных описаниях русскими источниками известны случаи применения татаро-монголами камнеметных машин, подобные виды осадного вооружения обычно называют вполне определенным термином - «пороки» (Каргер; 1950, с. 136-140 и др.; Майоров, 2016, с. 94-96). По мнению Н.Н. Воронина, «татарские пороки были тем решающим техническим средством, которое помогло татарам сломить героическую оборону почти всех русских городов» (Воронин, 1948, с. 468). Вполне реальным могло быть использование таких машин и в противостоянии татаро-монголов на территории Венгрии не только при осаде крепостей, но и, как подчеркивает В. Свентославский, в открытом поле, против скопления противников или его определенного порядка в его боевом построении. Как представляется, это вполне могло оказаться достаточно действенным и эффективным способом борьбы с противостоявшими татаро-монголам венгерскими и польскими подразделениями, имевшими в своем составе, например, тяжеловооруженных рыцарей.

Второй пример В. Свентославского - это описание поражения, нанесенного полякам «9 апреля 1241 г.» в «битве под Легницей» при «помощи боевых газов» и якобы «этот факт детально и очень образно был описан польским летописцем Яном Длугошем в его монументальном труде, представляющем историю польского королевства) (Свентославский, 2012, с. 373).

Я. Длугош, на чьих свидетельствах строится данный «факт», описывал ситуацию так: «Поляки не уступали и стремились победить. В течение некоторого времени обе армии вели ожесточенную борьбу между собой. Когда в ней погибла значительная часть выдающихся татар, поляки чуть не достигли полной победы. Татары, когда поредели их ряды, начали думать о бегстве. В татарской армии среди флагов был один, огромный, на котором был нарисован знак «Х». На верхушке древка этого флага было подобие отвратительной головы с заросшим подбородком. Когда татары, чуть отступив, пустились в бегство, знаменосец этого флага начал как можно сильнее трясти древко с головой, торчащей высоко на нем. Повалили из головы тотчас и распространились над всей польской армией пар, дым и мгла с отвратительным запахом. От этого невыносимого зловония сражающиеся поляки теряли сознание и, еще живые, ослабевали и становились неспособными к борьбе. Известно, что татары с начала своего существования и до настоящего времени всегда применяли в войнах искусство предсказаний, гаданий и чар. Применили его также в то время в борьбе с поляками» (цит. по: Свентославский, 2012, c. 374). На этом основании В. Свентославский делает следующий вывод: «Итак, польский летописец сохранил свидетельство об оружии татаро-монголов, неизвестном в тогдашней Европе, которое, скорее всего, представляло собой боевые газы. Реальность того польский историк объясняет так: «Монголы, будучи соседями Китая, могли именно оттуда перенять дымный порох и другие химические смеси, пригодные для использования во время боевых действий». Далее, ссылаясь на работы предшественников, например, на уже цитировавшуюся выше книгу С.А. Школяpa (Школяр, 1980), польский исследователь пишет: «Китайские и японские письменные источники говорят о применении монголами уже в XIII в. пороха, петард и снарядов с воспламеняющимися смесями против осаждаемых крепостей») (Свентославский, 2012, c. 374). Но другие авторы пишут: сообщения о первых осадах, например, «чжурчжэньских крепостей татаро-монголами свидетельствуют о применении ими камнеметного оружия опять-таки руками пленных и перешедших на их сторону китайских и чжурчжэньских «артиллеристов». Когда в 1232 г. монгольская армия окружила столицу чжурчжэней Кайфэн, именно эти воины обрушили на стены города зажигательные снаряды (хо пао) и уничтожили защитные средства осажденных. Однако сами монголы очень боялись порохового оружия чжурчжэней, и это послужило основной причиной их первого отсту- 
пления от крепости». Но уже через год татаро-монголы в союзе с сунскими войсками окружили последнюю столицу чжурчжэней, Цайчжоу, и осаждающие вновь применили снаряды хо пао, которыми сожгли настенные башни (Школяр, 1980, с. 178). Однако и эти уточнения вряд ли в пользу предположения В. Свентославского, впрочем, как и приводимые им этнографические свидетельства об использовании монголами дыма и пр. Интересно, что другой польский исследователь Г. Лабуда указывает на несколько известных сражений поляков с татаро-монголами, когда в январе 1241 г. татаро- монголы «прорвались к Висле, заняв Люлин и Завихост, отказавшиеся признать их власть», а один «из их отрядов проник до Рацибужа». Второй удар (февраль 1241 г.) «был обращен на Сандомир» - один из «главных опорных пунктов поляков на Висле». Тогда же (13 февраля 1241 г.) в сражении под Турском поражение потерпело и малопольское рыцарство. Затем татаро-монголы отходят назад, но «около 10 марта 1241 г. войска Байдара переправляются через Вислу, вновь оказавшись у Сандомира. Отсюда отряд Кайду отправляется в направлении Ленчицы с последующим выходом к Кракову; сам Байдар совершает рейд до Кельц. Прикрывая путь на Краков, польские отряды краковского воеводы Владимежа и сандомирского воеводы Пакослава 18 марта были разбиты под Хиельником. Воевода Владемеж погибает. Князь краковский и сандомирский - Болеслав Стыдливый с матерью (русской княгиней Гремиславой Ингваровной) и семьей покидает малопольскую столицу, укрывшись в Венгрии. 28 марта 1241 г. падет Краков.

Соединившись, отряды Байдара и Кайду, через Рацибурж и Ополе прорываются к столице Шленска - Вроцлаву. Жителей Шленской земли к обороне призвал князь Генрих Благочестивый. Воины из Малой Польши и южной части Великой Польши объединяются под воеводством Сулислава, брата краковского воеводы. Во главе верхнешленского воинства стал опольский Мешко; сам Генрих вел нижнешленское войско. Еще один отряд составляли иностранные рыцари, включая французских тамплиеров ${ }^{1}$ и др. ${ }^{2}$ Всем

В письме их великого магистра Понсе д'Обога французскому королю Людовику IX сообщалось, что в битве под Легницей тамплиеры потеряли более 500 человек, в т. ч. были и 6 рыцарей (Пашуто, 1977, с. 217).

Есть и сведения о нахождении в отрядегорняков из Злотой Гожи. Не исключается и нахождении в этом войском руководил, «должно быть, Болеслав - сын моравского маркграфа Дипольда». 9 апреля Генрих, шедший на соединение с чехами в битве, принял участие на Добра Поле под Легницей, в которой, как известно, погибло множество воинов, включая и Генриха (Пашуто, 1977, с. 216-217). Однако ни в этом перечне событий, как и в других, нет даже намека на то, что впоследствии описывал Я. Длугош.

Мы не случайно так подробно остановились на вышеотмеченных аспектах завоевательной кампании первой пол. XIII в., поскольку ни в Восточной Европе, ни в более западных регионах, в т. ч. и в случаях, когда татаро-монголам приходилось по несколько недель или даже месяцев осаждать многочисленные города, нести людские потери и пр., разные по своему происхождению и разнящиеся по степени своей информированности известные письменные источники ничего подобного не сообщают.

В. Свентославский почти сразу же и не без оснований совсем не исключает того, что: «некоторые сомнения может возбудить то обстоятельство, что эта летопись (Я. Длугоша - Авт.) возникла в середине XV века, т. е. уже два века спустя после сражения при Легнице». Однако, ссылаясь на мнение своих предшественников, польский автор полагает: «Как убедительно показал Г. Лабуда, Длугош писал о татаро-монгольском вторжении XIII в. в польские княжества на основе утраченной к настоящему времени летописи, в которой были записаны донесения непосредственных участников этих трагических для поляков событий» (Свентославский, 2012, с. 393). Не исключая реальности предположений об источниках информированности Я. Длугоша, тем не менее заметим: описание битвы под Легницей в других и более ранних сведениях не дают никаких оснований буквально доверять рассматривавшимся деталям их пересказа в версии Я. Длугоша, что и версию В. Свентославского делает фантастической.

Тем не менее сегодня можно встретить другие, не менее «интересные» версии о характере татаро-монгольского вооружения, впрочем, как и населения, например, в состав Золотой Орды так и не вошедшего, но испытавшего сильное воздействие военного дела же отряде и небольшого количества немецких рыцарей, которые еще в 1222 году от князя Генриха Бородатого небольшое селение Лососево (Lassusici) в Бенлевице. Князь Генрих обратился за помощью к чешскому королю Вацлаву I (1228-1253 гг.), пообещавшему привести войско (Пашуто, 1977, с. 217). 
Золотой Орды на свой собственный комплекс вооружения.

3. Я.В. Пилипчук о вооружении половцев, средневековых ингушей и войск эмира Тимура

В последние несколько лет историография исследований, связанных или посвященных разностороннему изучению золотоордынского периода истории Евразии, существенно расширилась, значительно увеличив и объем существующих библиографических обзоров (например: Золотая Орда..., 2013). Отмечая данный факт, укажем и на заметное увеличение работ, затрагивающих различного рода проблемы истории формирования и эволюционного развития комплекса вооружения XIII-XV вв. не только татаро-монголов, но и разных средневековых народов, оказавшихся в системе политико-экономического диктата Золотой Орды или же в контексте ее прямого либо опосредованного воздействия. Среди относительно новых по времени публикаций, связанных с изучением истории военного дела разных средневековых обитателей Евразии, мы обратили внимание лишь на несколько отдельных статей научного сотрудника отдела евразийской степи Института востоковедения им. А.Ю. Крымского и одновременно преподавателя кафедры истории и археологии славян Института исторического образования Национального педагогического университета им. М.П. Драгоманова (г. Киев, Украина), ныне д.и.н. Я.В. Пилипчука. Не останавливаясь на общей характеристике необычайного широкого (почти всеобъемлющего) спектра научных интересов, «всеохватывающе» пытающегося «отметиться» в рамках той или иной научной проблемы, здесь будет достаточным солидаризироваться с мнением других российских востоковедов Д.М. Тимохина и В.В. Тишина. Рецензируя одну из монографий украинского коллеги, они вполне справедливо подчеркнули: «Я. В. Пилипчук хорошо известен научной публике как весьма плодовитый автор с довольно широким кругом интересов - как в хронологическом, так и в региональном диапазонах - начиная от киммерийцев и скифов и заканчивая берберами и бурятами. В своих статьях он касается также довольно разнообразного круга вопросов - от миграций кочевников до политогенеза и дипломатии» (Тимохин, Тишин, 2020, с. 212) и не только. Неоднократно Я.В. Пилипчук касался и вопросов характеристики роли войн в жизни кипчаков (Пилипчук, 2011, с. 12-17), распространения среди кипчаков системы наёмничества (Пилипчук, 2012a, с. 337-346), особенностей воинского искусства кипчаков (Пилипчук, 2013, с. 187-209), а также специфики комплекса вооружения кипчаков (Пилипчук, 2012, с. 26-31), не говоря уже о военном деле финно-угров, обитателей Северного Кавказа и т. д. В качестве одного из примеров подобной характеристики, опубликованной украинским коллегой, является обобщающий обзор особенностей вооружения средневековых нахов ${ }^{3}$ Северного Кавказа, опубликованный им в одном из журналов Грузии. Небольшой отрывок этой статьи содержит оценку комплекса вооружения населения высокогорной Ингушетии преимущественно XIII-XV вв.

Среди множества дискуссионных аспектов рассматриваемых им проблем истории Я.В. Пилипчук утверждает: «В горную Ингушетию бежали кыпчаки, не желавшие покоряться монголам» (Пилипчук, 2019, с. 133). Несмотря на отсутствие соответствующей (и не только в этом случае) ссылки, подкрепляющей это утверждение, источник такой информации все же устанавливается и связан он с мнением М.В. Горелика (Горелик, 2011, с. 82), при помощи которого М.В. Горелик объяснял наличие в защитном вооружении горцев горной Ингушетии явных «степных» элементов, включая и металлические нагрудные бляхи (Нарожный, 2003, с. 245-274; Нарожный В., Нарожный Е., 2009, с. 373-387), до этого хорошо известные по их изображениям на половецких статуях. Но существует и другая точка зрения на этот счет, на следы явно тюркского влияния на горцев ${ }^{4}$ высокогорной Ингушетии ${ }^{5}$ и в особенности на их комплекс вооружения, явное предпочтение отдающая отнюдь не половцам, а тюркским мигрантам, в силу конкретных политических обстоятельств переместившимся на Северо-Восточный Кавказ с территории СевероЗападного Кавказа (Нарожный, Нарожный, 2009 , с. 376).

Ошибочным является и утверждение украинского коллеги и о том, что «стиль жизни предков ингушей был кочевническим»,

\footnotetext{
Этим названием Я.В. Пилипчук именует предков средневековых чеченцев и ингушей.

Обозначение средневековых предков ингушей «нахами» проблематично (Крупнов, 1971, с. 23-24 и сл.)

С географической точки зрения, эта территория все-таки Восточное Придарьялье.
} 
поскольку в конкретных ландшафтных условиях высокогорья они не только «выпасали скот» (Пилипчук, 2019, с. 133), но занимались они террасным земледелием, охотой, собирательством, кузнечными промыслами и пр. Известны примеры развитой деревообработки, косторезного ремесла и даже керамического производства (Нарожный В., 2012; Нарожный В., Нарожный Е., 2013, с. 321-324 и др.). Без конкретизации хронологии «несколькоэтажных боевых башен», которые «защищали их (Пилипчук, 2019, с. 133), утверждение выглядит как минимум спорно, т. к. такие башни относятся не к XIII-XV вв. Несмотря на существование у кавказоведов разных точек зрения на этот счет, время появления именно «боевых башен» в высокогорной Ингушетии, не только по наличию у них бойниц, явно предназначенных для огнестрельного оружия (Чахкиев,2019, с. 153-172), гораздо более позднее. Это, кстати, ныне подтверждает и использование для их датирования различных современных естественнонаучных методов (Результаты, 2015).

Рассматривая различные формы и средства «политической активности» горцев высокогорной Ингушетии, Я.В. Пилипчук попытался охарактеризовать известный ему комплекс вооружения горцев высокогорной Ингушетии, справедливо его представление начав с упоминания «защитного вооружения ингушей». Оно, отмечает наш коллега, включало в себя «конические и сфероконические шлемы»; фактически идентифицируя их с такими же боевыми наголовьями, чуть ранее отмеченными им у кипчаков (Пилипчук, 2012, с. 26-31). Но здесь необходимо более конкретное представление не такой уж и многочисленной коллекции шлемов из горной Ингушетии, кстати говоря, использовавшихся на протяжении довольно широкого временного диапазона. Тем самым указанное Я.В. Пилипчуком «подразделение» шлемов Ингушетии на две группы - явное упрощение, к тому же не дающее реального представления об образцах боевых наголовий из Ингушетии, их статистике, типологии и пр. Лишь отчасти она может быть сопоставлена с «половецкими» боевыми наголовьями с территории Северного Кавказа (Сальников, 2017, с. 91-106; Дмитриев, Нарожный, 2019, с. 608, рис. 6).

\footnotetext{
6 Данная статья А.В. Сальникова, к сожалению, имеет некоторые неточности, в т. ч. связанные и с обозначением авторства тех или иных рисунков шлемов.
}

Шлемы из высокогорной Ингушетии, несмотря на эпизодичный характер их находок, более разнообразны - среди них есть шлемы с высоким стреловидным шпилем (Чахкиев, Нарожный;1990, с. 140-141), а также шлем, полностью изготовленный из кольчужной сетки, но с навершием, ныне хорошо известным в Золотой Орде (Мужухоев, Нарожный, Чахкиев, 2017, с. 77-185), и др. (Нарожный В., Нарожный Е., 2012, с. 173-183) и т. д. Такое их разнообразие, к примеру, позволяет более детально и определенно рассматривать причины и пути распространении таких шлемов в высокогорье региона.

Что касается упоминаемых, причем опять без хронологических привязок, «мисюрок» из Ингушетии, известных более по музейным фондам и иллюстративному материалу (Чахкиев, 2019), то они, как и «стеганые шапки» из Ингушетии (Пилипчук, 2019, с. 133), ныне хорошо известны не только по изобразительным материалам XVIII-XIX вв. (Студенецкая, 1989, с. 21, рис. 1), но и в качестве археологического материала. Другими словами, мисюрки и стеганые («дольчатые») шапочки - это артефакты из воинского снаряжения совершенно иной исторической эпохи.

Немного странно выглядит упоминание Я.В. Пилипчуком просто «бармиц», опятьтаки без хронологической привязки; бармицы из Ингушетии сопровождали большинство из известных там шлемов либо же, при отсутствии бармицы, шлемы имели следы различного ее крепления к шлему. Бармицы известны на шлемах тоже на длительном отрезке времени (до XIX в. включительно), что Я.В. Пилипчуку было необходимо оговаривать.

Другие разновидности защитного вооружения, упоминаемые Я.В. Пилипчуком, «кольчатые панцыри, кольчуги, известные из Ингушетии, но и они очень разнообразны (Нарожный, 2011, с. 82-85; Чахкиев, 2019) и использовались в военной практике довольно широко, вплоть до окончания «Кавказской войны» XIX в. Археологические их дериваты немногочисленны, но все-таки известны (Нарожный, Нарожный, Чахкиев; 2005, с. 302 , рис. 3, 17-22, с. 304, рис. 5, 1; Нарожный, 2011 , с. 82-85; Чахкиев, 2019, с.105-122). Из высокогорья Ингушетии известны и находки остатков пластинчатого доспеха (Нарожный, 2011 , c. $82-85)$.

Я.В. Пилипчук справедливо упоминает использование в защитном вооружении средневековых ингушей налокотников, кото- 
рые, хотя и эпизодически, в разные годы были встречены в погребальных комплексах высокогорной Ингушетии не только XIII-XV (Нарожный, Чахкиев, 1990, с. 129-141), но и вплоть до окончания «Кавказской войны», впрочем, как и «боевые перчатки» (Чахкиев, 2019, с. 146-152), отмеченные нашим украинским коллегой, правда, опять-таки без конкретной или же относительной хронологической привязки.

Немногочисленны и находки остатков щитов, также справедливо упомянутых Я.В. Пилипчуком в арсенале горцев Ингушетии. Но, как и в других случаях, простая констатация данного факта, без каких-либо хронологических и видо-типологических оговорок таких находок, вслед за нашим украинским коллегой побуждает считать такие щиты из Ингушетии, скорее всего, идентичными «половецким щитам» из описаний вооружения половцев тем же автором, хотя это далеко не так. Остатки щитов из Ингушетии (Д.Ю. Чахкиев учел 6 таких образцов) - позднесредневековые (Чахкиев, 2019, с. 136-145). Остатки металлической обивки внешней поверхности и центральная мишень еще одного щита из раскопок Келийского могильника в Ингушетии (Нарожный, Чахкиев, 2003, с. 42) позволяют датировать этот щит XIII-XIV вв.; его М.В. Горелик соотносил с другими известными образцами с территории Северо-Западного Кавказа (Горелик, 2008, c. 158-189), где они сосредоточены более количественно (обзор находок: Дмитриев, Нарожный, 2019, с. 623-624). Сначала М.Л. Стрельченко, а затем В.А. Тарабанов, Р.Б. Схатум, М.В. Горелик, Д.Э. Василиненко, а вслед за ними и другие авторы - Л. Ильюков, Л.Э. Голубев, М.Ю. Федосов, Ю.Н. Федосова настаивают на сугубо адыго-черкесской атрибуции данной категории защитного вооружения. Тем не менее близкие и более ранние остатки типологически близких щитов известны и на территории Поросья (Dąbrowska, 1958, c. 158-159; Орлов, Моця, Покас, 1985, с. 13-14 и др.), что позволяет появление и распространение таких типов щитов на Северном Кавказе связывать с расселением здесь уже во второй пол. XIII в. черных клобуков (Нарожный, 2010, с. 94-95; Дмитриев, Нарожный, 2019, с. 599-641). Учет этих обстоятельств явно противоречит «картинам» политической активности средневековых предков ингушей в золотоордынское время.
Продолжая свою собственную характеристику набора вооружения средневековых предков ингушей, Я.В. Пилипчук утверждает: «Вооружены ингуши были луками со стрелами» (Пилипчук, 2019, с. 133), с чем не поспоришь. Однако коллега из Киева вновь игнорирует существующие работы своих предшественников на этот счет (Мамаев, Чахкиев, Даутова, 1983, с. 44-80), что не позволило бы вести речь о разных «конструктивных» особенностях луков XIII-XV вв. из Ингушетии, их размерах, «дальнобойности», способах стрельбы из них, как и в представлении о типологической вариабельности наконечников стрел. Не учитывает Я.В. Пилипчук и других специальных исследований своих предшественников, изучавших в т. ч. и упоминаемые им «однолезвийные мечи» из горной Ингушетии (Пилипчук, 2019, с. 133), впрочем, как «сабели», кстати говоря, имеющих свои видо-типологические и хронологические особенности - степень кривизны лезвий, особенности перекрестий, оформления рукоятей, ножен и креплений на них. К сведению указанного автора укажем и на сходство некоторых сабель из Ингушетии с саблями из соседних территорий Чечни и Грузии (Нарожный В., Нарожный Е., Чахкиев Д., 2005, с. 291-304 и ср.: Мамаев P., 2013, с. 74-84; Tsurtsumia, 2015, s. 160, fig. 1). Некоторые сабли из Ингушетии имели перекрестья и крепления на ножнах, находящие полные и близкие аналогии в материалах аланских раннесредневековых некрополей региона (Нарожный В., Нарожный Е., 2009, с. 373-387). И эти уточнения могли бы сильно скорректировать представления Я.В. Пилипчука о географии, способах и степени политической активности предков ингушей золотоордынского времени.

Аналогично «обезличенными» стали и просто упомянутые Я.В. Пилипчуком «кинжалы», констатация использования которых в горах Ингушетии приводилась в литератуpe неоднократно, но опять-таки без ссылок на источник информации и без каких-либо ссылок на упоминаемые артефакты, или же их хронологическая отсылка в этом случае не дает никакой дополнительной информации для читателя.

C сожалением остается констатировать подобное отношение нашего украинского коллеги к такой категории предметов вооружения из Ингушетии, как «копья и дротики». Они не только хорошо известны здесь 
(Чахкиев, 1988, с. 85-95), причем, с нередко устанавливаемой корреляцией таких находок с прижизненным статусом их владельцев из высокогорной Ингушетии, иногда связанных между собой при их жизни и узами кровного родства (Нарожный В., Нарожный Е., Чахкиев Д., 2017, с. 67-176). В некоторых случаях вполне определимы и этнокультурные истоки отдельных типов наконечников копий, явно заимствованных монголами, например, у чжурчженей (Нарожный, 2003, с. 261, рис. 9, 4) и у раннесредневековых киданей, впоследствии привнесенных монголами из глубин Центральной Азии в Восточную Европу, затем заимствованных предками ингушей и не только ими (Басов, Нарожный, Тихонов, 2003, с. 105-111). И эта категория находок могла дать Я.В. Пилипчуку вполне определенный повод и импульс для более глубокого понимания процессов политической активности предков ингушей в золотоордынское время.

Данный автор упоминает среди предметов вооружения средневековых ингушей и «секиры» (Пилипчук, 2019, с. 133), опять не указывая источник своей информации, что не позволяет судить о реальности данной информации. Известная мне, как представляется, пока единичная находка секиры - случайная и еще не опубликованная. Но она не из Ингушетии, а с территории Гудермесского района Чечни: крупная «стрелецкая секира» (бердыш?), вероятно, имевшая отношение к находившемуся где-то рядом Сунженскому «острогу» - российскому укреплению, построенному в 1651 г. на мысу, непосредственно в месте слияния рек Терек и Сунжа (Мамаев Х., Мамаев Р., Нарожный Е., 2012, с. 123, № 9).

На мой взгляд, явным упущением Я.В. Пилипчука является и то, что указав, вновь без ссылок на источники информации, на наличие в арсенале средневековых ингушей, например, «топоров», он не стал оговаривать, что известные топоры преимущественно не только из Ингушетии, но и из Чечни, также c широким хронологическим диапазоном использования, да и в функциональном отношении приоритет отдается не столько военному, сколько сугубо хозяйственному их использованию (Мамаев, Чахкиев, 1983, с. 68-78; Мамаев Х., Мамаев Р., 2011, с. 124-128).

Я.В. Пилипчук вполне справедливо упоминает и о существовании у средневековых ингушей не только «палиц», но и «шестоперов и булав» (Пилипчук, 2019, с. 133), «забывая», например, о находках там же синхронных им кистеней (Чахкиев, Голованова, Нарожный 1986, с. 70-80; Чахкиев, Нарожный, 2002, с. 4-8; Нарожный, Чахкиев, 2003, с. 126-153). Сегодня близкие и тождественные предметы такого же ударного вооружения известны и на сопредельных с Ингушетией территориях Чечни (Мамаев, 2016, с. 229-230; 2017, c. 54-59; 2019, с. 71-75; Mamaev, 2019, p. 2115-2119), Северной Осетии (Дружинина, Чхаидзе, 2013, с. 74-81), Кубани (Тарабанов, 1984, с. 164-172; Дружинина, 2017, с. 99-107), Грузии (Tsurtsumia, 2018, s. 87-114) и т. д. И эти разновидности предметов ударного вооружения, часть из которых, как представляется, является элементом «домонгольского» наследия (Хазария, Русь), вошедшего сначала в арсенал татаро-монголов, а затем вместе с центральноазиатскими привнесениями, дарами египетского султана (и их золотоордынскими копиями), хулагуидскими трофеями оказались и среди горских «заимствований» (Нарожный, Чахкиев, 2003, с. 126-153). И эти данные вполне могли скорректировать представления нашего киевского коллеги, но не скорректировали, превратившись в откровенные упущения, «констатирующие» лишь факт знакомства горцев региона с указанными разновидностями комплекса их вооружения, не больше, и не дающие стойкого и ясного представления читателю о хронологии появления и распространения тех или иных категорий вооружения, о многообразии, специфике военного дела средневековых ингушей, не говоря уже о специфике и контексте исторической обстановки, в рамках которой происходила эволюция их военного дела, в т. ч. и об их «роли и месте в политической истории Центрального Кавказа», что было обозначено в качестве основной задачи рассматриваемого исследования Я.В. Пилипчука.

Подобные «недочеты» и даже откровенные казусы встречаются и в другой части рассматриваемой статьи Я.В. Пилипчука. Например, он упоминает и некоего «Телара (Талевра) Гагиева», принявшего якобы участие в сражении предков ингушей «против чагатайских войск Тимура». И в этом случае источник информации не указывается, хотя речь идет об «истории», не так давно сложившейся из достаточно «вольной» атрибуции давнего археологического комплекса - разрушенного воинского погребения из сел. Верхний Алкун, опубликованного в 1990 г. (Чахкиев, Нарожный, 1990, с. 129-141). Несмотря на разру- 
шенный характер захоронения, его погребальный инвентарь был представлен шлемом, кольчугой, саблей, набором как минимум от двух колчанных наборов. Датируется комплекс предметов несколькими монетами нач. XV в.; в наборе было и два фрагмента керамики с проработанными по их внешним поверхностям надписями, выполненными при помощи грузинского алфавита «ассомтаврули» (по свидетельству специалистов, обе надписи воспроизводили, скорее всего, какое-то местное имя - «ТАЛЕВР»7, начертанное при помощи знаков грузинского алфавита) (Чахкиев, Нарожный, 1990, с. 129-141). Позднее, на что мы уже указывали специально (Нарожный, Чахкиев, 2010, с. 237-239), М.В. Горелик указывал на сугубо золотоордынский характер комплекса вооружения из данного комплекса, из-за чего верхнеалкунский комплекс в 3-м томе «Истории татар» ошибочно был атрибутирован как комплекс золотоордынского воина. Я.В. Пилипчук, вероятно, в своем упоминании о «Теларе (Талевре) Гагиеве» опирается на упомянутый (см. прим. 7) научно-популярный фильм «Со ва», который, однако, в качестве достоверного источника рассматриваться не может.

Довольно странным представляется и его вывод об «области Симсим», упоминаемой источниками (Шами и Йезди), локализация которой на Северо-Восточном Кавказе разными авторами (Э.В. Ртвеладзе, Х.А. Хизриев, М.К. Джиоев и др.) предлагалась различно и неоднократно, на что наш киевский коллега не обращает никакого внимания, но при этом полагает: эту «область» «скорее можно связать с тюрками (? - Е.Н.) Золотой Орды, а не горцами» (Пилипчук, 2019, с. 133-134).

Приведенные примеры обращения Я.В. Пилипчуком к различным историкокультурным проблемам Северного Кавказа, его населения и комплекса его вооружения заставляет вновь обращаться к выводам уже упоминавшейся рецензии Д.М. Тимохина и В.В. Тишина на одну из его недавних моно- графий. Оба рецензента вполне однозначно подчеркнули: «рецензенты приходят к выводу, что данная работа (Я.В. Пилипчука - Е.Н.) не может быть признана вносящей какой-либо вклад в изучение социальной истории кыпчаков» (Тимохин, Тишин, 2020, с. 210). Впрочем, как и то, что «сведение фактического материала, почерпнутого из источников в том виде, в каком он может с ними работать, получается бессистемным, несмотря на его обилие. Все эти свойства сводят сущность работы, по сути, к компиляции, местами добротной, местами неумелой. Работа воспринималась бы совсем по-иному, если бы автор преподносил ее не как исследование, а как, например, научно-популярное издание или справочное пособие. Именно в этом, наверное, состоит наибольшая ценность рецензируемой книги» (Тимохин, Тишин, 2020, с. 224).

К сожалению, в своей «публикационной активности» Я.В. Пилипчук довольно часто допускает и откровенные «ляпы», не задумываясь над их (при отсутствии существования критического восприятия) возможными последствиями. К примеру, размышляя уже над проблемой: «Грузия и тюрки» в конце XIV - XV вв., указанный исследователь, хотя и лаконично, описывает поход войск эмира Тимура на грузинскую столицу г. Тбилиси. Тимур совершает его, «услышав, что там (в Тбилиси - Е.Н.) находится царь Баграт без войска». Но из-за того, что «защитники города два-три раза делали храбрые вылазки против Тимура», до тех пор «пока Тимур не нашел гору, с которой было удобно обстреливать город из ружей и пушек (выделено мной Авт.). Царь был вынужден явиться к Тимуру и сдать крепость» (Пилипчук, 2016, с. 59).

Подобные утверждения встречаются и в других статьях указанного автора, вряд ли способствуя дальнейшему и объективному восприятию вооружения интересующего нас исторического отрезка времени, запутывают, дезориентируют, перенося явно недостоверные сведения на страницы многих и нередко солидных научных изданий.

\section{ЛИТЕРАТУРА}

Археология Евразийских степей. 2017. № 5. 355 с.

Басов В.И., Нарожный Е.И., Тихонов М.П. О двух типах наконечников копий с территории Северного Кавказа // МИАСК. Вып. 2 / Отв. ред. Е.И. Нарожный. Армавир: РИЦ АГПИ, 2003. С. $105-111$.

Сегодня речь идет о том, что «перевод этот содержал ошибку, видимо, вызванную опечаткой, при которой две последние буквы поменяли местами. Во всяком случае, недавно в научно-популярном фильме «Со ва» надпись была представлена уже в варианте «Талерв», прочитанном как «Телар во» [http://ingliterature.ru] (Maмаев Р., Мамаева Р., Мамаев Х., с. 334). 
Воронин Н.Н. Крепостные сооружения // История культуры Древней Руси. Домонгольский период . Т. I: Материальная культура / Под ред. Н.Н. Воронина, М.К. Каргера и М.М. Тихановой. М.- Л., 1948. C. 439-470.

Горелик М.В. Монголы и подвластные народы в Золотой Орде (этносоциальная самоидентификация и ее внешнее выражение) // Золотоордынское наследие.: Материалы второй международной научной конференции «Политическая и социально-экономическая история Золотой Орды», посвященной памяти М. А. Усманова (Казань, 29-30 марта 2011 г.) Вып. 2 / Отв. ред. и сост. И.М. Миргалеев. Казань: ООО «Фолиант», ИИ им. Ш. Марджани АН РТ, 2011 С. 77-89.

Горелик М.В. Черкесские воины Золотой Орды (по археологическим данным) // Вестник КБИГИ. 2008. Вып. 15. С. 158-189.

Дмитриев А.В., Нарожный Е.И. Два захоронения воинов-кочевников XIII XIV вв. из СевероВосточного Причерноморья (к истории формирования комплекса вооружения Золотой Орды) // Генуэзская Газария и Золотая Орда. Т. 2. / Ред. С.Г. Бочаров, А.Г. Ситдиков. Кишинев: Stratum Plus, 2019. С. 599-641.

Дружинина И.А. Шестопер из кургана у станицы Абинская (по материалам раскопок В.Г. Тизенгаузена в Кубанской области, 1879 г.) // Археология Евразийских степей. 2017. № 5. С. 99-107.

Дружинина И.А., Чхаидзе В.Н. О старых и новых находках предметов вооружения из североосетинского святилища Реом // Очерки средневековой археологии Кавказа. К 85-летию со дня рождения В.А. Кузнецова / Отв. ред. В. И. Козенкова. М.: ИА РАН, 2013. С.74-81.

Золотая Орда: библиографический указатель / Отв. ред. Э.Г. Сайфетдинова. Казань: ИИ им. Ш.Марджани АН РТ, 2013.412 с.

Кадырбаев А.Ш. Польша и татаро-монгольские народы в историческом пространстве // История и современность. 2008. №1. С. 76-98.

Каргер М.А. Археологические исследования древнего Киева. Киев (Львов): Изд-во АН Укр. ССР. 1950. $252 \mathrm{c}$.

Крупнов Е.И. Средневековая Ингушетия. М.: Наука, 1971. 207 с.

Майоров А.В. Завоевание русских земель в 1237-1240 годах // Золотая Орда в мировой истории. / Отв. ред. И. Миргалеев и Р. Хаутала. Казань: ИИ им. Ш. Марджани АН РТ, 2016. С. 89-113.

Мамаев Р.Х. Из истории изучения булав, найденных на Центральном Кавказе // Вестник Академии наук Чеченской Республики. 2017. №3(36).С. 54-59

Мамаев P.X. Навершие средневековой булавы из ГИМа (К истории археологии Чечни)// Вестник Академии наук Чеченской Республики. 2019. № 7(47). С. 71-75.

Мамаев Р.X. Об одном типе бронзовых булав, найденных на Северном Кавказе // Изучение и сохранение археологического наследия народов Кавказа. XXIX «Крупновские чтения». Материалы международной научной конференции (Грозный, 18-21 апреля 2016 г.) / Отв. ред. Х. М. Мамаев. Грозный: Чеченский гос. ун-т, 2016. С. 229-230.

Мамаев P.X. Средневековые сабли из Майртупа // Вестник Академии наук Чеченской Республики. 2013. № 3 (20). C. 74-84.

Мамаев Р.Х., Мамаева Р.А., Мамаев Х.М. О новых находках сосудов с надписями из склепового могильника «Цой-Пхеде» (Малхиста) // Наука и молодежь. Всероссийская научно-практическая конференция студентов, молодых ученых и аспирантов (Грозный, 27-28 октября 2016). / Отв. ред. Р.А. Кутуев. Грозный: Изд-во:ЧГУ, 2016. С. 333-336.

Мамаев Х.М. Мамаев Р.X. Топор из Мескетов и некоторые вопросы изучения позднесредневековыХ башен Чечни // Вестник Академии наук Чеченской Республики. 2011. № 1 (14). С. 124-128.

Мамаев Х.М. Мамаев Р.Х., Нарожный Е.И. Археологические памятники Гудермесского района ЧР (материалы к археологической карте) // Вестник Академии наук Чеченской Республики. 2012. № 1 (16). C. $121-130$.

Мамаев Х.М., Чахкиев Д.Ю. О назначении железных позднесредневековых топоров из Чечни // Хозяйство и хозяйственный быт /Отв. ред. В.Б. Виноградов. Грозный, 1983. С. 68-78.

Мамаев Х.М., Чахкиев Д.Ю., Даутова Р.А. Лук и стрелы у позднесредневековых вайнахов // Новые археологические материалы по средневековой истории Чечено-Ингушетии /Отв. ред. В.Б. Виноградов. Грозный: ЧИНИИСФ, 1983. С. 44-80.

Мужухоев М.Б., Нарожный Е.И., Чахкиев Д.Ю. Воинское погребение №33 Келийского могильника (Горная Ингушетия) // Археология Евразийских степей. 2017. №5. С. 77-185. 
Нарожный B.E. Население высокогорной Ингушетии в XIII-XV веках. Автореф. Дисс. ... канд. истор. наук. Владикавказ: СОГУ, 2012. 26 с.

Нарожный В.Е., Нарожный Е.И. Горная зона Восточного Придарьялья и золотоордынские владения (К изучению динамики взаимоотношений) // Диалог городской и степной культур на евразийском пространстве // Донские древности. Вып. 10 / Отв. ред. А.А. Горбенко. Азов: Изд-во Азовского музеязаповедника, 2009. С. 373-387.

Нарожный В.Е., Нарожный Е.И. Погребение №67 Келийского могильника (Горная Ингушетия) // Поволжская археология. 2012. №2. С. 173-183.

Нарожный B.Е., Нарожный Е.И. Находки ремесленного инструментария в горной Ингушетии XIII-XIV вв. // Третья Абхазская международная археологическая конференция: Проблемы древней и средневековой археологии Кавказа / Отв. ред. М.Т. Кашуба, А.Ю.Скаков. Сухум: ИИМК РАН; АбИГИ им. Д. И. Гулиа АНА; РУП «Дом печати», 2013. С. 321-324.

Нарожный В.Е., Нарожный Е.И., Чахкиев Д.Ю. Погребения «копейщиков» Келийского могильника в высокогорной Ингушетии // Археология Евразийских степей. 2017. № 5. С. 67-176.

Нарожный Е.И. Пластины доспеха из полуподземного склепа № 10 Келийского могильника (Горня Ингушетия) // Военное дело Золотой Орды. Проблемы и перспективы изучения / Отв. ред. И. М. Миргалеев. Казань: Изд- во: ИИ им. Ш. Марджани АН РТ, 2011. С. 82-85.

Нарожный Е.И. К вопросу о происхождении позднесредневековых щитов Северо-Западного Кавказа // Археологический журнал. 2010. № III-IV. C. 94-95.

Нарожный Е.И. Нарожный В.Е., Чахкиев Д.Ю. Погребение №15 Келийского могильника (Горная Ингушетия) // МИАСК. Вып. 5 / Отв. ред. Е.И. Нарожный. Армавир: Международная Академия Наук. 2005. С. 291-304.

Нарожный Е.И. О половецких изваяниях и святилищах XIII-XIV вв. Северного Кавказа и Дона // Степи Европы в эпоху средневековья. Т. 3. Половецко-золотоордынское время / Гл. ред. А.В. Евглевский. Донецк: ДонНУ, 2003. С. 245-274.

Нарожный Е.И. Юбилейные заметки (К 60-летию Сергея Борисовича Буркова) // Археологические раскопки на Северном Кавказе. Сборник избранных научных работ С.Б. Буркова: статьи, материалы, рецензии. К 60-летию со дня рождения /Отв. ред. М.С. Гаджиев. Махачкала: МавраевЪ, 2019. C. 371-393.

Нарожный Е.И., Чахкиев Д.Ю. Еще раз о комплексе вооружения из средневекового захоронения у селения Верхний Алкун в горной Ингушетии // МИАСК. Вып.11 /Отв. ред. Е.И. Нарожный. Армавир: РИЦ АГПИ, 2010. С. 237-239.

Нарожныци Е.И., Чахкиев Д.Ю. О воинских щитах из горной Ингушетии.. О воинских щитах из горной Ингушетии // Десятые чтения по археологии Средней Кубани. /Отв. ред. В.Б. Виноградов и Е.И. Нарожный. Армавир: РИЦ АГПИ, 2003. С. 42-43.

Нарожный Е.И., Чахкиев Д.Ю. О находках некоторых образцов ударного и защитного вооружения на Северном Кавказе (XIII-XV вв.) // МИАСК. Вып. 2 / Отв. ред. Е.И. Нарожный. Армавир: РИЦ АГПИ, 2003. C. 126-153.

Орлов Р.С., Моия А.П., Покас П.М. Исследования летописного Юрьева на Росси и его окрестностей // Земли Южной Руси IX-XIV вв. / Под ред. П.П. Толочко. К.: Наукова думка, 1985. С. 41-60.

Пашуто В.T. Монгольский поход вглубь Европы // Татаро-монголы в Азии и Европе /Отв. ред. С.Л. Тихвинский. М.: Наука, ГРВЛ, 1977. С. 210-227.

Пилипчук Я.В. Война в жизни кыпчаков. Противостояние с другими кочевниками // Вестник КазНПУ им. Абая. Серия: Исторические и социально-политические науки. 2011. № 4 (31). С. 12-17.

Пилипчук Я.В. Оружие и защитное снаряжение кипчаков // Вестник КазНПУ им. Абая. Серия: Исторические и социально-политические науки. 2012. №4 (35). С. 26-31.

Пилипчук Я.В. Военное искусство кыпчаков // Тюркские кочевники Евразии (кимаки, кипчаки, половцы ...) / Отв. ред. С.Г. Кляшторный, В.А. Иванов, И.К. Загидуллин. Казань: Ихлас, 2013. С. 187-209.

Пилипчук Я.В. Грузия и тюрки в конце XIV в. // Вестник КазНПУ им. Абая. Серия: Исторические и социально-политические науки, 2016. №4(5371-1). С. 58-65.

Пилипчук Я.В. Кыпчакские наемники на службе у правителей Евразии // Степи Европы в эпоху средневековья. Т. 10. Половецкое время /Отв. ред. А.В. Евглевский. Донецк, ДонГУ 2012б. С. 337-346.

Пилипчук Я.В. О месте нахов в политической истории Центрального Кавказа // Amirani. 2019. № 32. C. $129-146$. 
Результаты радиоуглеродных датировок. Заключение по результатам дендрохронологического исследования в 2015 г. URL: http://ing-arheologiya.ru/index.php/nauka/85-otchet-po-dendro-rabotam2015-g (дата обращения 05.12.2020)

Савенко С.Н. Размышлении о юбилеях, общем деле, соратничестве, взаимоподдержке и дружбе: к 60-летию кавказоведа, доктора исторических наук Евгения Ивановича Нарожного // МИАСК. Вып. 18. / Отв. ред. Е.И. Нарожный. Армавир-Краснодар: РИЦ АГПИ, 2020. С. 364-377.

Сальников A.B. К вопросу об атрибуции некоторых шлемов Северного Кавказа XII-XVI вв. // Теория и практика археологических исследований. 2017. №3 (19). C. 91-106. DOI: https://doi.org/10.14258/ tpai(2017)3(19).-06

Свентославский В. Боевые газы в армии средневековых монголов // Военная археология. Оружие и военное дело в исторической и социальной перспективе. СПб.: Изд-во Гос. Эрмитажа, 1998, С. $295-297$.

Свентославский В. Боевые газы в военном деле монголо-татар // ЗВОРАО: Новая серия. Т.1(XXVI) / Отв. ред. В.И. Масон. СПБ: Петербургское востоковедение, 2012. С. 393-379.

Студенецкая Е.Н. Одежда народов Северного Кавказа. XVIII-XX вв.М.: Наука, 1989. 288 с.

Тарабанов В.A. Средневековые погребения Ленинохабльского могильника (по раскопкам 1975 г.) // Вопросы археологии Адыгеи /Отв. ред. Н.В. Анфимов, П. У. Аутлев. Майкоп., 1984. С. 164-172.

Тимохин Д.М., Тишин В.В. Рецензия на монографию о социальной истории кыпчаков в IX-XIII вв.: Пилипчук Я.В. Соціальна історія кипчаків у IX-XIII ст. Київ - Вінниця: Національний педагогічний університет ім. М. П. Драгоманова, Тов «Твори», 2018. 340 с. // История, археология и этнография Кавказа. 2020. T.16. №1. С. 210-226 DOI: https://doi.org/10.32653/CH161210-226

Чахкиев Д.Ю. , Нарожный Е.И. Погребение знатного горского воина начала XV века из селения Верхний Алкун (Чечено-Ингушетия) // Военное дело древнего и средневекового населения Северной и Центральной Азии / Отв. ред. Ю.С. Худяков. Новосибирск: НГУ, 1990 .С. 129-141

Чахкиев Д.Ю. Копья и дротики у позднесредневековых вайнахов // Новые материалы по археологии и этнографии Чечено-Ингушетии / Отв. ред. М.Б. Мужухоев. Грозный: Чеч.- Инг. кн-е изд-во, 1988. С. 85-95.

Чахкиев Д.Ю. Оружие и вопросы военного искусства позднесредневековых ингушей и чеченцев (XIII-XVIII вв.). Магас, 2019. 380 с.

Чахкиев Д.Ю., Голованова С.А., Нарожный Е.И. О хронологии и методах применения некоторых позднесредневековых образцов вооружения у вайнахов // Проблемы хронологии погребальных памятников Чечено-Ингушетии /Отв. ред. В.Б. Виноградов. Грозный: Чеч.- Инг. кн-е изд-во, 1986. С. $70-80$.

Чахкиев Д.Ю., Нарожный Е.И. Образцы ударного оружия золотоордынского времени на Северном Кавказе // Научный вестник Ингушского госуниверситета. 2002 №1. С. 4-8. $406 \mathrm{c}$.

Школяр С.А. Китайская доогнестрельная артиллерия (Материалы и исследования). М.: Наука, 1980.

Dąbrowska E. Kurhany Rassawskie // Archeologia 1958.VIII, Z.1. S. 122-167 (in Polish).

Mamaev R. Kh. On the four-poinied pommel of the Medieval Mace found in Chechnya // The European Proceedings of Social \& Behavioural Sciences EpSBS, 2019. P. 2115-2119 (in English).

Tsurtsumia M. Medieval Sword and Sabre from the Georgian National Museum // Acta Militaria Mediaevalia. 2015. Vol. XI. S. 159-172.

Tsurtsumia M. The Mace in Medieval Georgia // Acta Militaria Mediaevalia. Vol. 14, 2018. S.. 87-114.

\section{Информация об авторе:}

Нарожный Евгений Иванович, доктор исторических наук, Заслуженный работник культуры Кубани, главный специалист, Непубличное акционерное общество (НАО) «Наследие Кубани», (г. Краснодар, Россия).

\section{REFERENCES}

2017. Arkheologiia Evraziiskikh stepei (Archaeology of Eurasian Steppes) 5. (in Russian).

Basov, V. I., Nnarozhny, E. I., Tikhonov M., P. 2003. In Narozhnyi, E. I. (ed.). Materialy i issledovaniya po arkheologii Severnogo Kavkaza (Materials and Studies on the Archaeology of the North Caucasus). 2. Armavir: Archaeological Research Centre of Armavir State Pedagogical Institute, 105-111 (in Russian).

Voronin, N. N. 1948. In Voronin, N. N., Karger, M. K., Tikhanova, M. M. (eds.). Istoriia kultury Drevnei Rusi. Domongol'skii period. T. 1. Material'naia kultura (History of the Culture of Ancient Russia. Pre-Mongol Period. Vol. I: Material Culture) Moscow; Leningrad, 439-470 (in Russian). 
Gorelik, M. V. 2008. In Vestnik Kabardino-Balkanskoog Instituta gumanitarnykh issledovanii (Bulletin of Kabardino-Balkarian Institute for Humanitarian Studies) 15, 158-189 (in Russian).

Gorelik, M. V. 2011. In Mirgaleev, I. M. (ed.). Zolotoordynskoe nasledie. Materialy Mezhdunarodnoi nauchnoi konferentsii «Politicheskaia i sotsial'no-ekonomicheskaia istoriia Zolotoi Ordy». 29 - 30 marta 2011 $g$ (Heritage of the Golden Horde. Proceedings of the International Scientific Conference "Political and SocioEconomic History of the Golden Horde." March 29-30, 2011.) 2. Kazan: "Foliant" Publ.; Institute of History named after Sh. Mardzhani, Tatarstan Academy of Sciences Publ., 77-89 (in Russian).

Dmitriev, A. V., Narozhny, E. I. 2019. In Bocharov, S. G., Sitdikov, A. G. (ed.). Genuezskaia Gazariia i Zolotaia Orda (The Genoese Gazaria and the Golden Horde) 2. Series: Archaeological Records of Eastern Europe. Kazan; Kishinev: "Stratum Plus" Publ., 599-641 (in Russian).

Druzhinina, I. A. 2017. In Arkheologiia Evraziiskikh stepei (Archaeology of Eurasian Steppes) 5. 99-107 (in Russian).

Druzhinina I. A., Chkhaidze V. N. 2013. In Kozenkova, V. I. (ed.). Ocherki srednevekovoi arkheologg Kavkaza. K 85-letiyu so dnia rozhdeniia V. A. Kuznetsova (Essays on Medieval Archaeology of the Caucasus. To the 85th Anniversary of V. A. Kuznetsov). Moscow: Institute of Archeology of RAS, 74-81 (in Russian).

Sayfetdinova, E. G. (eds.). 2013. Zolotaia Orda: bibliograficheskii ukazatel'(Golden Horde: Bibliographic Index) Kazan: Kazan: Institute of History named after Shigabuddin Mardzhani, Tatarstan Academy of Sciences (in Russian).

Kadyrbaev, A. Sh. 2008. In Istoriia i sovremennost'(History and Contemporaneity) 1, 76-98 (in Russian).

Karger, M. A. 1950. Arkheologicheskie issledovaniia drevnego Kieva (Archaeological Studies of Ancient Kiev). Kiev (Lviv): Academy of Sciences of the Ukrainian SSR (in Russian).

Krupnov, E. I. 1971. Srednevekovaia Ingushetiia (Medieval Ingushetia). Moscow: "Nauka" Publ. (in Russian).

Mayorov, A.V. 2016. In Mirgaleev, I. M., Khautala, R. (eds.). Zolotaya Orda v mirovoi istorii (The Golden Horde in world history). Kazan: Institute of History named after Shigabuddin Mardzhani, Tatarstan Academy of Sciences, 89-113 (in Russian).

Mamaev, R. Kh. 2017. In Vestnik Akademii nauk Chechenskoi Respubliki ( Bulletin of the Academy of Sciences of the Chechen Republic) 36 (3), 54-59 (in Russian).

Mamaev, R. Kh. 2019. In Vestnik Akademii nauk Chechenskoi Respubliki ( Bulletin of the Academy of Sciences of the Chechen Republic) 47 (7), 71-75 (in Russian).

Mamaev, R. Kh. 2016. In Mamaev, Kh. M. (ed.). Izuchenie i sokhranenie arkheologicheskogo naslediia narodov Kavkaza. XXIX «Krupnovskie chteniya» po arkheologii Severnogo Kavkaza» (Study and preservation of archaeological heritage of the peoples of Caucasus. The XXIX-th Krupnov's reading. Krupnov Readings on the Archaeology of the North Caucasus). Grozny: Chechen State University, 229-230 (in Russian).

Mamaev, R. Kh. 2013. In Vestnik Akademii nauk Chechenskoi Respubliki ( Bulletin of the Academy of Sciences of the Chechen Republic) 20 (3), 74-84 (in Russian).

Mamaev, Kh. M., Mamaev, R. Kh. 2011. In Vestnik Akademii nauk Chechenskoi Respubliki ( Bulletin of the Academy of Sciences of the Chechen Republic) 14 (1), 124-128 (in Russian).

Mamaev, R. Kh., Mamaeva, R. A., Mamaev, Kh. M. 2016. In Kutuev, R. A.(ed.). In Nauka i molodezh (Science and Youth). Grozny: Chechen Sate University, 333-336 (in Russian).

Mamaev, Kh. M., Mamaev, R. Kh., Narozhny, E. I. 2016. In Vestnik Akademii nauk Chechenskoi Respubliki (Bulletin of the Academy of Sciences of the Chechen Republic) 16(1), 333-336 (in Russian).

Mamaev, Kh. M., Chakhkiev, D. Yu. 1983. In Vinogradov, V. B. (ed.). Khoziaistvo i khoziaistvennii byt (Economy and Economic Life). Grozny, 68-78 (in Russian).

Mamaev, Kh. M., Chakhkiev, D. Yu., Dautova, R. A. 1983. In Vinogradov, V. B. (ed.). Novye arkheologicheskie materialy po srednevekovoi istorii Checheno-Ingushetii (New Archaeological Materials on the Medieval History of Chechen-Ingushetia). Grozny: TINIEST, 44-80 (in Russian).

Muzhahoev, M. B. Narozhnyi, E. I., Chakhkiev, D. Y. 2017. In Arkheologiia Evraziiskikh stepei (Archaeology of Eurasian Steppes) 5. 77-185 (in Russian).

Narozhny, V. E. 2012. Naselenie vysokogornoi Ingushetii v XIII-XV vekakh (Population of High-Mountain Ingushetia in the 13th-15th Centuries) Thesis of Diss. of the Candidate of Historical Sciences. Vladikavkaz: North Ossetian state University (in Russian).

Narozhny, V. E., Narozhny, E. I. 2009. In Gorbenko, A. A. (ed.). Dialog gorodskoi i stepnoi kul'tur na Evraziiskom prostranstve. (Dialogue of the Urban and Steppe Cultures in the Eurasian Space). Series: 
Antiquities of the Don 10. Azov: Azov Historical-Archaeological and Palaeontological Museum-Reserve Publ., 373-387 (in Russian).

Narozhny, V. E., Narozhny, E. I. 2012. In Povolzhskaia arkheologiia (Volga River Region Archaeology) (2), 173-183 (in Russian).

Narozhny, V. E., Narozhny, E. I. 2013. In. Kashuba, M. T., Skakov, A. Yu. (eds.). Tret'ia Abhazskaia mezhdunarodnaia arkheologicheskaia konferentsiia: Problemy drevnei i srednevekovoi arkheologii Kavkaza (The Third Abkhazian International Archaeological Conference "Issues of the Ancient and Medieval Archaeology of the Caucasus). Sukhumi: IIMK RAS; Abkhaz Institute for Humanitarian Research named after D. I. Gulia ANA; RUP "Dom Pechati" Publ., 321-324 (in Russian).

Narozhny, V. E., Narozhny, E. I., Chakhkiev, D. Yu. 2017. In Arkheologiia Evraziiskikh stepei (Archaeology of Eurasian Steppes) 5. 167-176 (in Russian).

Narozhny, E. I. 2003. In Evglevskii, A. V. (ed.-in-chief). Stepi Evropy v epokhu srednevekov'ia (Steppes of Europe in the Middle Ages) 3. Polovetsko-zolotoordynskoe vremia (The Cuman-Golden Horde Period). Donetsk: Donetsk National University, 245-274 (in Russian).

Narozhny, E. I. 2010. In Arkheologicheskii zurnal (Archaeological Journal) III-IV, 94-95 (in Russian).

Narozhny, E. I. 2011. In Mirgaleev, I. M. (ed.). Voennoe delo Zolotoi Ordy. Problemy i perspektivy izucheniia (Military Affairs of the Golden Horde. Study Issues and Prospects). Kazan: Institute of History named after Sh. Mardzhani, Tatarstan Academy of Sciences Publ., 82-85 (in Russian).

Narozhny, E. I. 2019. In Gadzhiev, M. S. (ed.). Arkheologicheskie raskopki na Severnom Kavkaze. Sbornik izbrannykh nauchnykh rabot S.B. Burkova (Archaeological Excavations in the North Caucasus. Collection of Selected Scientific Works by S. B. Burkov). Makhachkala: "Mavraev" Publ, 371-393 (in Russian).

Narozhny, E. I., Narozhny, V. E., Chakhkiev, D. Yu. 2005. In Narozhnyi, E. I. (ed.). Materialy i issledovaniya po arkheologii Severnogo Kavkaza (Materials and Studies on the Archaeology of the North Caucasus). 5. Armavir: International Academy of Sciences, 291-304 (in Russian).

Narozhny, E. I., Chakhkiev, D. Yu. 2003 In Vinogradov, V. B., Narozhnyi, E. I. (ed.). Desiatye chteniia po arkheologii Srednei Kubani (Tenth Readings on the Archaeology of the Middle Kuban). Armavir: Archaeological Research Centre of Armavir State Pedagogical Institute, 42-43 (in Russian).

Narozhny, E. I., Chakhkiev, D. Yu. 2003. In Narozhnyi, E. I. (ed.). Materialy i issledovaniya po arkheologii Severnogo Kavkaza (Materials and Studies on the Archaeology of the North Caucasus). 2. Armavir: Archaeological Research Centre of Armavir State Pedagogical Institute, 126-153 (in Russian).

Narozhny, E. I., Chakhkiev, D. Yu. 2010. In Narozhnyi, E. I. (ed.). Materialy i issledovaniya po arkheologii Severnogo Kavkaza (Materials and Studies on the Archaeology of the North Caucasus) 10. Armavir: Archaeological Research Centre of Armavir State Pedagogical Institute, 237-239 (in Russian).

Orlov, R. S., Motsya, A. P., Pokas, P. M. 1985. In Tolochko, P. P. (ed.). Zemli Yuzhnoi Rusi IX-XIV vv. (Southern Russian Lands in the 9th-14th cc.). Kiev: "Naukova dumka" Publ., 41-60 (in Russian).

Pashuto, V. T. 1977. In Tikhvinskii, S. L. (ed.).Tataro-mongoly v Azii i Evrope (Tatar-Mongols in Asia and Europe) Moscow: "Nauka" Publ., 210-227 (in Russian).

Pilipchuk, Ya. V. 2013. In Kliashtornyi, S. G., Ivanov, V.A., Zagidullin, I.K. Tiurkskie kochevniki Evrazii (kimaki, kipchaki, polovtsy ...) (Turkic Nomads of Eurasia (Kimeks, Kipchaks, Cumans...)). Kazan: Ikhlas Publ., 187-209 (in Russian).

Pilipchuk, Y. V. 2011. In Vestnik KazNPU (Bulletin of the Kazakh National Pedagogical University named after Abai. Series: Historical and socio-political Sciences. Series: Historical and Socio-Political Sciences) 4 (31), 12-17 (in Russian).

Pilipchuk, Ya. V. 2012. In Evglevskii, A. V. (ed.-in-chief). Stepi Evropy vepokhu srednevekov'ia (Steppes of Europe in the Middle Ages). 10. Polovetskoe vremia (Polovtsian Time). Donetsk: Donetsk National University, 337-346 (in Russian).

Pilipchuk, Ya. V. 2012. In Vestnik KazNPU (Bulletin of the Kazakh National Pedagogical University named after Abai. Series: Historical and Socio-Political Sciences. Series: Historical and Socio-Political Sciences) 4 (35), 26-31 (in Russian).

Pilipchuk, Ya. V. 2016. In Vestnik KazNPU (Bulletin of the Kazakh National Pedagogical University named after Abai. Series: Historical and Socio-Political Sciences. Series: Historical and Socio-Political Sciences). 4(5371-1), 58-65 (in Russian).

Pilipchuk, Ya. V. 2019. In Amirani. 32, 129-146 (in Russian).

Rezul'taty radiouglerodnykh datirovok. Zakliuchenie po rezul'tatam dendrokhronologicheskogo issledovaniia (Radiocarbon Dating Results. Conclusion on the Results of Dendrochronological Studies in 
2015) Available at: http://ing-arheologiya.ru/index.php/nauka/85-otchet-po-dendro-rabotam-2015-g (Accessed 05.12.2020) (in Russian).

Savenko, S. N. 2020. In Narozhnyi, E. I. (ed.). Materialy i issledovaniya po arkheologii Severnogo Kavkaza (Materials and Studies on the Archaeology of the North Caucasus). 18. Armavir: Archaeological Research Centre of Armavir State Pedagogical Institute, 364-377 (in Russian).

Salnikov, A. V. 2017. In Teoriia I praktika arheologicheskikh issledovaniy (Theory and practice of archaeological research) 19 (3), 91-106. DOI: https://doi.org/10.14258/tpai(2017)3(19).-06 (in Russian).

Svetoslavsky, V. 1998. In Voennaia arkheologiia. Oruzhie $i$ voennoe delo $v$ istoricheskoi $i$ sotsial'noi perspective (Military Archaeology. Armament and Military Art in the Historical and Social Perspective). Saint Petersburg: The State Hermitage Museum, 295-297 (in Russian).

Svetoslavsky, V. 2012. In Mason, V. I. (ed.). Zapiski Vostochnogo ondeleniia Russkogo arkheologicheskogo obshchestva (Notes of the Eastern Branch of the Russian Archaeological Society) 1 (XXVI). Saint-Petersburg: Petersburg Oriental studies, 393-379 (in Russian).

Studenetskaya, E. N. 1989. Odezhda narodov Severnogo Kavkaza. XVIII-XX vv. (Clothing of the Peoples of the North Caucasus. 18th-20th cc.). Moscow: "Nauka" Publ. (in Russian).

Tarabanov, V. A. 1984. In Anfimov, N. V., Outlev, P. U. (eds.). Voprosy arkheologii Adygei (Issues of Archaeology of Adygea). Maykop, 164-172 (in Russian).

Timokhin, D. M., Tishin, V. V. 2020. In Istoriia, arkheologiia i etnografiia Kavkaza (History, Archaeology and Ethnography of the Caucasus) Vol. 16, No. 1, 2020, Pp. 210-226. DOI: https://doi.org/10.32653/ CH161210-226 (in Russian).

Chakhkiev, D. Yu., Narozhny, E. I. 1990. In Khudiakov, Yu. S. (ed.). Voennoe delo drevnego $i$ srednevekovogo naseleniia Severnoi i Tsentral'noi Azii (Military Art of the Ancient and Medieval Population of Northern and Central Asia). Novosibirsk: Novosibirsk State University, 129-141 (in Russian).

Chakhkiev, D. Y. 1988. In Muzhahoev, M. B. (ed.). Novye materialy po arkheologii i etnografii ChechenoIngushetii (New Materials on the Archaeology and Ethnography of the Chechen-Ingush Republic). Grozny: Checheno-Ingushskoe knizhnoe izdatel'stvo Publ., 85-95 (in Russian).

Chakhkiev, D. Yu. 2019. Oruzhie i voprosy voennogo iskusstva pozdnesrednevekovykh ingushei $i$ chechentsev (XIII-XVIII vv.). (Weapons and Issues of Military Art of the Late Medieval Ingush and Chechens (13-18 centuries). Magas (in Russian).

Chakhkiev D. Yu., Golovanova S. A., Narozhny E. I. 1986. In Vinogradov, V. B. (ed.). Problemy khronologii pogrebal'nykh pamiatnikov Checheno-Ingushetii (Issues of of Chronology of the Funerary Monuments of Chechen-Ingushetia). Grozny: Checheno-Ingushskoe knizhnoe izdatel'stvo Publ., 70-80 (in Russian).

Chakhkiev, D. Yu., Narozhny, E. I. 2002. In Nauchnyi vestnik Ingushskogo gosuniversiteta (Scientific Bulletin of the Ingush State University) 1, 4-8 (in Russian).

Shkolyar,. S. A. 1980. Kitaiskaia doognestrel'naia artilleriua (Materialy i issledovaniua) (Chinese Pre-Fire Artillery (Materials and Studies). Moscow: "Nauka: Publ. (in Russian).

Dąbrowska, E. 1958. In Archeologia. VIII, Z.1, 122-167 (in Polish).

Mamaev R.Kh. 2019.In The European Proceedings of Social \& Behavioural Sciences EpSBS, 2115-2119 (in English).

Tsurtsumia, M. 2015. In Acta Militaria Mediaevalia. XI. 159-172 (in English).

Tsurtsumia, M. 2018. In Acta Militaria Mediaevalia. 14, 87-114 (in English) .

\section{About the Author:}

Narozhnyi Evgeny I. Doctor of Historical Sciences, Honoured Cultural Worker of Kuban, Leading Specialist of NJSC "Heritage of Kuban", Krasnoarmeiskaya Str. 16, Krasnodar, 350063, Russian Federation; zai_ein@mail.ru 